\title{
Ahmed Ghaith
}

\section{Abstract}

Tourists around the world have become more environmentally conscious, and the demand for green accommodation has experienced a rapid growth. In this background, the form of accommodation known as "eco-lodges" have gained a huge popularity, especially among those who are seeking environment friendly wilderness experiences. Extensive studies on characterization of visitors seeking accommodation in eco-lodges have been documented in the tourism literature. However, empirical studies conducted on understanding attitudes, perceptions, characteristics of guests staying in eco-lodges in the Egypt destinations are lacking. A better understanding of such information on tourists is vital in ecotourism planning and development. The purpose of this study was to expand the current literature by determining the demographic characteristics, Accommodation characteristics, and service quality perception differences between each guests group in Eco-lodge guests on Egypt. A self-administrated questionnaire was used to collect data from 202 guests in Eco-lodge on Fayoum and Dahkla. A random samplesampling plan was used to collect samples. Frequencies, percentages were calculated. Then, oneway analysis of variance (One-Way ANOVA) to determine which group differs significantly from each other the study found that eco-lodge guests were typically highly educated, ages of 25 less than 40, from Egypt and other country who worked full time and had a very high household annual income. On average, guests stayed in Egyptian Eco-lodge for 1-4 days and stayed at the Eco-lodge for three to four nights and visited with their friends and family to learn and explore nature and a new culture. The internet, travel guidebooks and recommendations from friends and relatives were the three most important sources of information that influence on guests' decision making the process to choose the Eco-lodge. Results indicate that the perceived Eco-lodge service quality differs according to the guests' education level and age group. As the eco-lodge business grows and becomes more competitive, managers must learn about and cater to their market group in order to position themselves favourably in the global marketplace.

Keywords: Eco-lodge guests- demographic characteristics-Demographics-Attitudes, Perceptions

\section{Introduction}

As ecotourism continues to establish itself in the global economy, the demand for well planned, and environmentally sound lodging facilities is enormously increasing. This phenomenon has competitively positioned Eco-lodges in the market. The reason for this is that Eco-lodges have enabled visitors to interact with the natural and cultural surrounding worldwide and prioritised conservation (Mehta, 2000).

Eco-lodges continue to evolve. Consequently, many developers and investors all over the world, especially in the hospitality industry, have opted to abandon conventional designs and facilities. Eco-lodge designs are more profitable; less sophisticated and have minimum negative impact involved in their development as well as their positive impact on biodiversity areas. (CeballosLascurain, 2001, IFC, 2004). A World Bank study, conducted in 2004 reveals that, the ecolodge market is expected to grow by an average rate of $10 \%$ per year over five decades (IFC, 2004).

The ecolodge industry emerged in the 1980s and grew rapidly over the following decades (Sanders \& Halpenny, 2001); however, there was a relatively slow increase in the literature concerning ecolodges. The scope of the ecolodging literature predominantly focused on definitions, the physical environment, best practices, and sustainability evaluations (Wight, 
1997). Studies also examined ecolodge economics and finance (Sanders \& Halpenny, 2001), goals (Osland \& Mackoy, 2004), selection and evaluation of lodging alternatives (Mackoy \& Osland, 2004), planning (Barany et al., 2001) and marketing (Lai \& Shafer, 2005). Few studies profiled the characteristics of Eco-lodge patrons. This is a disadvantage because without knowledge of the guest base, Eco-lodge managers may fail to meet the needs of their guests, ultimately compromising the sustainability of their business.

The purpose of this research was to determine the demographic and characteristics of a sample of Eco-lodge guests at 14 Eco-lodges in Fayoum governorate and Dakhla oasis of Egypt. Also, this study compared the perceived Eco-lodge service quality differs according to some of the guests' characteristics.

\section{Eco-lodge Definition and Characteristic}

The sustainable development has impacted all facets of society and all sectors of the global economy. This includes the hospitality and tourism industry, which has attempted, over the years, to incorporate sustainable practices in its various segments. In recent years, however, there has been a significant impetus toward incorporating green practices into all areas of the lodging segment based on three triple line of sustainable development, which are conservation surrounding area resources, development local economy and provision of high-quality sightseeing tour utilizing resources (Jackson, 2010).

In the accommodations sector a new type of accommodation emerges that is the Eco-lodge that leads to many research and studies conducted by expert to determine Eco-lodge concept. Ecolodges are ne, small, specialist, nature-dependent, green lodging and environmentally-friendly accommodation units with a focus on protected natural and social environment through development local economy (Black and Crabtree, 2007: Jackson,2010: Chan, 2010: Carmody,2008).

Conceptually, Eco-lodge accommodation is defined as "a nature dependent tourist lodge that meets the philosophy and principles of ecotourism" with an emphasis on ecological sensitivity and a focus on the delivery of educational or experiential concepts (Mehta, 2000). Parallel to ecotourism principles and philosophy, Eco-lodges can play a role in contributing to enhanced tourist awareness of and support for, conservation and participation in environmental management practices. This is further supported by the need to improve sustainable management and operations for guest accommodation. In Egypt context Eco-lodges concept depends on planning, designing and construction with totally matching with natural area and community cultural (TDA, 2004).

According to The international and local Eco-lodge Guidelines, an Eco-lodge should meet the following criteria, which are the key principles and characteristics of Eco-lodges: They are as follows: designed in harmony with the local natural and cultural environment, using the principles of sustainable architecture, maximize the use of renewable energy resources and the use of renewable materials for construction, where possible using recycled materials, work in harmony with communities offering jobs with a wide range of responsibilities and employment via contracts with other vendors, provide benefits to local conservation and research initiatives both public and private and offer excellent interpretative programs to educate the clients about the local environment and culture.(TDA, 2008:Mehta, 2005:IFC, 2004 and Hawkins et al., 1994). 


\section{Eco-lodge Guests Characteristic}

The previous studies conducted to explore Eco lodge guests profile and Characteristics on different context showed that there are night factors used to determine them. These factors are: Age, Education, Income, status, Employment status, Country of residence, trip length, Party composition, and length of stay and major sources of information (Ban and Ramsaran, 2016: Adalilar et al., 2015 : Perera, 2015: Ramcharjee, 2012 and kawn, 2010). The researcher showed these studies in Table 1.

Table1: Eco-lodge Guests Profile \& Characteristic Studies

\begin{tabular}{|c|c|c|c|c|c|}
\hline \multirow[b]{2}{*}{$\begin{array}{l}\text { Items of } \\
\text { compression }\end{array}$} & \multicolumn{5}{|c|}{ Authors } \\
\hline & $\begin{array}{l}\text { Ramcharjee, } \\
2012\end{array}$ & $\begin{array}{l}\text { Adalilar, et al., } \\
2015\end{array}$ & kawn, 2010 & $\begin{array}{l}\text { Perera, } \\
2015\end{array}$ & $\begin{array}{l}\text { Ban and } \\
\text { Ramsaran, } \\
2016\end{array}$ \\
\hline Age & $50-57$ & $35-54$ & $46-55$ & $26-35$ & $30-49$ \\
\hline Education & $\begin{array}{l}\text { Bachelor's } \\
\text { degree or } \\
\text { above }\end{array}$ & $\begin{array}{l}\text { Graduate - } \\
\text { Ph.D. Degree } \\
\text { Holders }\end{array}$ & $\begin{array}{l}\text { Bachelor Degree \& } \\
\text { Master's or } \\
\text { Doctoral Degree }\end{array}$ & $\begin{array}{l}\text { Post- } \\
\text { graduate } \\
\text { degree }\end{array}$ & Post-secondary \\
\hline Income & & $\begin{array}{l}2500 \text { and } \\
\text { above }\end{array}$ & more than 14000 & $\begin{array}{l}\text { Above } \\
100,000\end{array}$ & \\
\hline Status & & $\begin{array}{l}\text { Married \& } \\
\text { Single }\end{array}$ & & Married & \\
\hline $\begin{array}{l}\text { Employment } \\
\text { status }\end{array}$ & full-time & & Employed full time & & Employed \\
\hline Nationality & USA & & USA & & \\
\hline Trip length & 8-11 days & & $8-11$ & & \\
\hline $\begin{array}{l}\text { Party } \\
\text { composition }\end{array}$ & $\begin{array}{l}\text { Spouse } \\
\text { Family }\end{array}$ & & $\begin{array}{l}\text { Spouse } \\
\text { Family }\end{array}$ & $\begin{array}{l}\text { With } \\
\text { another } \\
\text { adult }\end{array}$ & \\
\hline length of stay & $5-3$ & & 3 & 3 & $2-4$ nights \\
\hline $\begin{array}{l}\text { Major } \\
\text { sources of } \\
\text { information }\end{array}$ & Internet & & Internet & Internet & \\
\hline
\end{tabular}

Source: Ban and Ramsaran, 2016; Adalilar et al., 2015;

Perera, 2015; Ramcharjee, 2012; kawn, 2010.

\section{Perceived Service Quality}

The service quality construct is mostly conceptualized in the context of service marketing literature (Lee and Yoo 2000). Therefore, it deals with the concept of perceived service quality. According to Parasuraman et al., (1991), perceived service quality is the extent to which a firm successfully serves the purpose of customers.

Customers determine the perceived or cognitive value of service based on their experience with the service delivered. Ghobadian, Speller and Jones, (1994) stated that customers' expectations, service delivery process, and service outcome have an impact on perceived service quality. Yoo and Park, (2007) found that employees, as an integral part of the service process, are a critical element in enhancing perceived service quality. Furthermore, Edvardsson, (2005) pointed out 
that service quality perceptions are formed during the production, delivery and consumption process. The author concluded that customers' favorable and unfavorable experience, as well as their positive and negative emotions, may have an important impact on perceived service quality. Similarly, O'Neill and Palmer, (2003) have reported that customers' perceptions of service quality may, to a large extent, be influenced by the degree of their prior experience with a particular service.

There have few studies of eco-lodge attributes, preferences, satisfaction from a guest point of view. Chan, (2010-2005) and Chan and Baum, (2007) concluded that there are other keys for eco-guests, the four key satisfy experience of guest in eco-lodge accommodation: a unique architecture design/features, pristine natural environment and attractions, relaxed and peaceful atmosphere, novelty and eco- recreation-based activities by other meaning the eco-lodge guest satisfaction affected by the environment activities and human/ social aspects. Sheena et at., (2013) conducted a study to determine the eco-tourists' preferences on the eco-lodge attributes, which were included nature-based attraction, services and comfort, location, surrounding and landscaping and structure and material. The nature-based attraction is the main preferences attributes in this study. In addition to there are three studies indicated in the previous section in our current study on services quality in ecotourism and Eco lodge section.

Khan, (2003) stated that eco-tourists tend to expect businesses to be environmentally friendly and prefer services that are courteous, informative, and trustworthy. In addition, physical facilities that were environmentally appropriate and equipment that minimizes environmental degradation were found more important to the eco-tourists. Ban and Ramsaran, (2016) concluded that the eco-guest view the service quality in eco-lodge including three dimensions are eco-friendly practices, eco-activities, and eco-learning. Lu and Stepchenkova, (2012) identified 26 attributes of eco-lodge experiences that affect eco-tourists' satisfaction with eco-lodge stays. These attributes can be further aggregated into seven categories. The first is eco-lodge settings, which includes ambiance, eco-friendliness, grounds and/or surroundings, lodge amenities, noise, and other guests. The second is nature or nature-based activities, natural attractions, and weather, while the third is rooms, including room and bathroom decor and layout, room amenities, room and bathroom facilities and insect problems. The fourth category is service, which involves customer service, tour and tour guide services, reservation processes, management policies, extra services, and restaurant services. The fifth is food (i.e. food quality), and the sixth is location or closeness to town, closeness to attractions and accessibility. The last is value for money, including room rates, food and drink prices and other prices.

It should be noted that according to some authors, perceived service quality has been accepted as an antecedent of customer satisfaction (Oliver, 1997 and Churchill and Suprenant, 1982). Cronin and Taylor (1994, 1992s) argued that performance is the measure that best explains customer' perceptions of service quality and the measurement of service quality, customer satisfaction and behavior attention based only on perception is enough. Therefore, this study has adopted this viewpoint.

Therefore, the SERVPERF measure has been successfully adapted for measuring service quality in different service industries and Some studies have directly applied service quality paradigms within the context of the hospitality industry such as hotels (Al Khattab and Aldehayyat, 2011: Raspor, 2010: Karunaratne and Jayawardena, 2010: Yilmaz, 2009: Akbaba, 2006 and Nadiri and Hussain, 2005).

Stevens et al., (1990) and Wong et, al., (1999) presented a new scale to evaluate the service quality expectation for guest in the hotel sector, which is content of five dimensions in the 
original SERVQUAL model, but the dimension has different scale items where the proposed scale is formed LODSERV has 25 scale items, while HOLSERV has 27 scale items, these items matching with hotel industry concept and characteristic of hotel guest.

In, 2003 Getty and Getty indicated the service quality index, which has included 25 scale items instead of 22 scale items in SERQUAL original model, while Tefera and Govender, (2014) stated that the hotels service quality performance model is content of two dimensions: the first one is tangible and the second one is intangible. Also, in the framework develop model to measure service quality in eco-hotel or green hotel Bastic and Gojcic, (2012) stated that the model included four dimensions: the first is Environmentally friendly and healthy equipment, the second is Eco-behavior of hotel staff, the third is Efficient use of energy and water, the finally is Bio-food.

Khan, (2003) proposed ECOSER; a scale comprising six dimensions to measure the service quality expectations of Eco-tourists. They are as follows: eco-tangibles, assurance, reliability, responsiveness, empathy other tangibles, While Saez et al., (2007) suggested RE, a scale comprising five dimensions to measure the service quality expectations and perception in of Ecotourists in rurally located tourism lodgings. They are as follows: personnel response, complementary offer, tourist relations, tangible elements, and empathy.

Yusof et al., (2014) developed that a scale comprising seven dimensions to measure the service quality expectations and perception of Eco-tourists in lodging on ecotourism destination. They are as follows: sustainability, sustainable practices, tangibility, reliability, responsiveness, assurance, and empathy. Also, Said et al., (2013) modified The ECOSERV instrument developed by Khan in 2003 to measure visitors' expectations and perceptions on services quality. A scale comprising five dimensions to measure the service quality expectations and perception, but this modified instrument is customized scale items to 18 instated of 26 items.

Ban and Ramsaran, (2016) developed the ECOPERF a scale comprising eight dimensions to measure the service quality perception of Eco-tourists in eco-lodge. They are added three new dimensions as follows: eco-friendly practices (using alternative, sustainable means to reduce energy and water consumption, recycling and eco-certified product), eco-activities (nature-based, leisure and recreational and adventurous activities), eco-learning (ecological/ environmental knowledge and culture), in addition to depended the five original dimension, but there are has different statement and different number of statement in the whole of scale.

\section{Research Method}

The research method is quantitative. The study used a questionnaire to collect data from guests. The questionnaire comprised a series of Five-point Likert scales, statements adapted from the literature review. These are Khan, (2003), Bastic and Gojcic, (2012), Said et al., (2013) and Ban and Ramsaran, (2016),...etc, whose studies relate SQ development in Eco-lodge. The final form includes 41 items used to measure the six constructs of the developed model. The six constructs are, empathy " (measured by 5 indicators), ", assurance " (measured by 5 indicators), " responsiveness " (6 items), , reliability " (6 indicators), , tangibility " (15 indicators), , Ecoactivities and sustainable practices " (6 indicators). The form included a number of questions to collect Eco-lodge guests' characteristic " gender, age, martial statue, annual household income, employment status, most recent academic qualification. Questionnaires were distributed and collected face to face by researcher for a two-month period employing random sampling technique. Surveyed Eco-lodges $\mathrm{s}$ is located in Fayoum governorate and Dakhla oasis, where most Eco-lodge exist (Mosalhy, 2018 and Hagag, 2018). The researcher was staying in the 
selected Eco-lode three times per week and chooses randomly guests to complete the questionnaires. 385 questionnaires were sent out for data collection purposes from Eco-lodgee guests in Fayoum governorate and Dakhla oasis. 276 questionnaires were returned and were found usable, and the other 74 were not completed by respondents. Accordingly, the response rate was $71.6 \%$ which is found sufficient.

\section{ECO-SERVQUAL Scale Development}

In this research, the researcher scanned the hotel and Eco lodge model from the previous study of service quality to develop ECO-SERQUAL model to measuring the perceived quality of ecoguest in Egyptian Eco-lodge context. The process of developing the scale goes through four stages, as follows: The first explore the service quality model in general, hotel and eco-lodge. The second comprising between the general scale, hotel, and eco-lodge model. The third stage is matching between the scale dimension and statement in three different cases to develop new one as below. The final stage is producing the development scale of ECO-SERQUAL, which is using in this research.

\section{Data analysis}

The descriptive analysis, reliability and validity were analysed using SPSS-16 to highlight the main characteristics of the sample and the demographic data. Then, one-way analysis of variance (One-Way ANOVA) to determine which group differs significantly from each other.

\section{Results}

Descriptive Statistics

Profiling Eco-lodge Guest

Table 2: Eco-lodge Guest Gender

\begin{tabular}{|l|c|c|}
\hline \multirow{2}{*}{ Gender } & \multicolumn{2}{|c|}{ Total } \\
\cline { 2 - 3 } & Frequency & $\%$ \\
\hline Male & 81 & 40.1 \\
\hline Female & 114 & 56.4 \\
\hline Total & 195 & 96.5 \\
\hline
\end{tabular}

Table 2 shows that $56.4 \%$ of Eco-lodge guests are female, while male guests $40.1 \%$. This means the need to focus more likely on female expected services for marketing purposes.

Table 3: Eco-lodge Guest Age Group

\begin{tabular}{|l|c|c|}
\hline \multirow{2}{*}{ Age group } & \multicolumn{2}{|c|}{ Total } \\
\cline { 2 - 3 } & Frequency & $\%$ \\
\hline Less than 25 & 35 & 17.3 \\
\hline 25 to less than 40 & 118 & 58.4 \\
\hline 40 to less than 60 & 30 & 14.9 \\
\hline 60 and above & 12 & 5.9 \\
\hline Total & 195 & 96.5 \\
\hline
\end{tabular}

Table 3 shows that the most frequent age group among the eco-lodge guests from the guests was 25 to less than 40 age group (58.4\%), followed by the less than 25 age group (17.3\%), and the 40 to less than 60 age group (14.9\%). This finding agrees partially with (Perera, 2015 and Ban and Ramsaran, 2016) who found that the most frequent age group among the eco-lodge guests from the guests between 26 to 49 age group. This means the need to focus more likely on Eco-lodge age group between 25 to 40 expected services for Eco-lodge marketing plan. 
Table 4: Eco-lodge Guest Martial statue

\begin{tabular}{|l|c|c|}
\hline \multirow{2}{*}{ Martial Statue } & \multicolumn{2}{|c|}{ Total } \\
\cline { 2 - 3 } & Frequency & 53.5 \\
\hline Single & 108 & 38.6 \\
\hline Married & 78 & 2.5 \\
\hline Widowed & 5 & 2.5 \\
\hline Divorced & 5 & 97.0 \\
\hline Total & 196 & \\
\hline
\end{tabular}

A lot of Eco-lodge guest are Single guests (53.5\%) (Table 3). The second largest group of guests contained married guests $(38.6 \%)$, and the third and four groups were those who were widowed and divorced (8.9\%). The previous some of the results agree with Adalilar et al., (2015) who mentioned that most of Eco-lodge guests are single guests. This means the need to focus more likely on single guest expected service for Eco-lodge marketing plan.

Table 5: Eco-lodge Guest Education level

\begin{tabular}{|l|c|c|}
\hline \multirow{2}{*}{ Education } & \multicolumn{2}{|c|}{ Total } \\
\cline { 2 - 3 } & Frequency & $\%$ \\
\hline High school education & 6 & 3.0 \\
\hline Bachelor degree & 124 & 61.4 \\
\hline Master degree & 51 & 25.2 \\
\hline Ph.D. degree & 15 & 7.4 \\
\hline Total & 196 & 97.0 \\
\hline
\end{tabular}

Table 5 indicates that the majority of Eco-lodge guest are well educated: $61.4 \%$ had a bachelor's degree. About $3.0 \%$ of the guest had in high school education. There is an agreement in the literature that Eco-tourists are highly educated, with the majority possessing at least a bachelor's degree (Ramcharjee, 2012, Adalilar, et al., 2015, Kwan et al., 2010). This means the Egyptian Eco-lodge market caters to highly educated guests, similar to most other ecotourism markets.

Table 6: Eco-lodge Guest Nationality

\begin{tabular}{|l|c|c|}
\hline \multirow{2}{*}{ Nationality } & \multicolumn{2}{|c|}{ Total } \\
\cline { 2 - 3 } & Frequency & $\%$ \\
\hline Egyptian & 141 & 69.8 \\
\hline Canadian & 4 & 2 \\
\hline Danish & 4 & 5.4 \\
\hline French & 11 & 2 \\
\hline English & 4 & 7.4 \\
\hline German & 15 & 2.0 \\
\hline Italian & 4 & 1 \\
\hline Spanish & 2 & 2.0 \\
\hline Swedish & 4 & 1 \\
\hline Turkish & 2 & 1 \\
\hline American & 2 & 100 \\
\hline Total & 202 & E \\
\hline
\end{tabular}

Table 6 reported that the four most frequently visiting nationalities to the Eco-lodge are Egyptian (69.8\%), German (7.4\%), France (5.4), Italian, Canadian, Danish, English and Swedish (2.0) respectively. Many studies found that the largest groups of Eco tourists were domestic tourists. For example, Wight (1996a) found that the largest groups of Eco-tourists to Canada are Canadians. Higham et al., (2001) found that the largest group of visitors to New Zealand ecotourism operations was from New Zealand. This means the Egyptian Eco-lodge owner and 
manager need focus more on domestic Eco-tourist and international Eco-tourists for marketing purpose.

Table 7: Eco-lodge Guest Employment Status

\begin{tabular}{|l|c|c|}
\hline \multirow{2}{*}{ Employment Status } & \multicolumn{2}{|c|}{ Total } \\
\cline { 2 - 3 } & Frequency & $\%$ \\
\hline Student & 18 & 8.9 \\
\hline Unemployed & 11 & 5.4 \\
\hline Self-employed & 45 & 22.3 \\
\hline Full-time Employee & 104 & 51.5 \\
\hline Part-time Employee & 7 & 3.5 \\
\hline Retired & 9 & 4.5 \\
\hline Total & 194 & 96.0 \\
\hline
\end{tabular}

Table 7 shows that $51.5 \%$ of Eco-lodge guests are full-time Employee and the following are the remaining employment status: 22.3\% Self-employed, 8.9 students, 5.4\% Unemployed, 4.5\% Retired 3.5\% Part-time Employee. These results agree with Ban and Ramsaran, 2016, Ramcharjee, 2012, Kwan et al., 2010 who mention that the majority of Eco-lodge guests are fulltime employee. This means the eco-guest have more experience and knowledge which leads to more marketing efforts.

Table 8: Eco-lodge Guest Party Composition

\begin{tabular}{|l|c|c|}
\hline \multirow{2}{*}{ Visiting Eco-lodge with } & \multicolumn{2}{|c|}{ Total } \\
\cline { 2 - 3 } & Frequency & $\%$ \\
\hline Alone & 11 & 5.4 \\
\hline Spouse & 19 & 9.4 \\
\hline Family & 50 & 24.8 \\
\hline Friends & 114 & 56.4 \\
\hline Total & 194 & 96.0 \\
\hline
\end{tabular}

Many guests visit Eco-lodge with their Friends (56.4\%), followed by families (24.8\%), Spouse (9.4\%), and Alone (5.4\%). The Egypt Eco-lodge market is particularly attractive to Friends and Family. Perera, (2015) stated that Eco-tourists most often travel as couples. Ramcharjee, (2012) and Kwan et al., (2010) found that families make up a sizeable portion of Eco-tourists; however, neither study distinguishes between adult families and families with children. Wight, (1996a) found that families with children were a common group of Eco-tourists. The provision of increased levels of service designed for families with children may provide the Egypt Eco-lodges with a competitive advantage.

Table 9: Eco-lodge Guest Average Length of Stay

\begin{tabular}{|l|c|c|}
\hline \multirow{2}{*}{$\begin{array}{l}\text { The average length of stay at } \\
\text { eco-lodge }\end{array}$} & Frequency & $\%$ \\
\cline { 2 - 3 } 1-3 days & 173 & 85.6 \\
\hline 4-7 days & 20 & 9.9 \\
\hline More than 11 days & 1 & .5 \\
\hline Total & 194 & 96.0 \\
\hline
\end{tabular}

Table 9 shows that Average length of stay at the Eco-lodge was three nights (85.6\%). About 9.9\% of the Eco-guests stayed from four to seven days. There is an agreement in the literature review that the average lengths of Stay in Eco-lodge are 1-3 days (Ban and Ramsaran, 2016, Perera, 2015, Ramcharjee, 2012 and kwan et al., 2010). 
International Journal of Heritage, Tourism and Hospitality Vol. (13), No. (2), September, 2019

By: Faculty of Tourism and Hotels, Fayoum University

Table 10: Eco-lodge Guest Annual Income

\begin{tabular}{|l|c|c|}
\hline \multirow{2}{*}{ Annual Income (USA) } & \multicolumn{2}{|c|}{ Total } \\
\cline { 2 - 3 } & Frequency & $\%$ \\
\hline Less than $3000 \$$ & 49 & 24.3 \\
\hline $3000: 6000 \$$ & 35 & 17.3 \\
\hline $6000: 9000 \$$ & 24 & 11.9 \\
\hline $9000: 12000 \$$ & 4 & 2.0 \\
\hline More than $12000 \$$ & 60 & 29.7 \\
\hline Total & 172 & 85.1 \\
\hline
\end{tabular}

Table 10 indicates that $29.7 \%$ of eco-guests had an annual income more than $12000 \$$. Followed by $24.3 \%$ from those less than 3000 \$, while $17.3 \%$ from the sample from US3000 to 6000\$. (Ban and Ramsaran, 2016, Perera, 2015, Ramcharjee, 2012, Kwan et al., 2010). Thus, the Eco-lodge managers provide guests with eco-activities, cultural and heritage activities from the local area with a high price.

Table 11: Eco-lodge Guest Major Sources of Information

\begin{tabular}{|l|c|c|}
\hline \multirow{2}{*}{ Sources of Information } & \multicolumn{2}{|c|}{ Total } \\
\cline { 2 - 3 } & Frequency & $\%$ \\
\hline Internet & 78 & 38.6 \\
\hline Travel agent & 13 & 6.4 \\
\hline Word of mouth & 33 & 16.3 \\
\hline Travel guidebook & 2 & 1.0 \\
\hline Magazine articles & 4 & 2.0 \\
\hline Personal experience & 43 & 21.3 \\
\hline Friends/relatives & 95 & 47.0 \\
\hline Environmental association & 2 & 1.0 \\
\hline Social media & 42 & 20.8 \\
\hline Eco-lodge Website & 13 & 6.4 \\
\hline
\end{tabular}

When asked about the most important sources of information used for Eco-lodge selection, the highest source of information for Eco-guest in Eco-lodge was 47.0\% Friends/relatives, followed by $38.6 \%$ from the Internet, $21.3 \%$ from Personal experience and only $16.3 \%$ from Word of mouth (Tabel 11). It is noteworthy to observe the importance of Friends/relatives and the Internet to these guests. The in almost all studies of Eco-tourists, Friends/relatives and the Internet did make the top four information sources used by Eco-tourists (Perera, 2015, Ramcharjee, 2012, Kwan et al., 2010). This study shows how the internet encourages Eco-lodge selection as well as the movement of tourists among several different destinations during a trip. Thus, Eco-lodge manager should in consideration how marketing the service on the internet such as website, social media, and engineering website search.

Differences by gender, age, education and martial statue in ECO-SERQUAL Model

Table 12: Gender Differences in ECO-SERQUAL Model

\begin{tabular}{|c|c|c|c|c|c|c|}
\hline \multicolumn{2}{|l|}{ Factors } & $\mathrm{M}$ & SD & T-Value & Sig & Sig \\
\hline \multirow{2}{*}{ Empathy } & Male & 3.7 & 1.0 & .018 & \multirow{2}{*}{.100} & \multirow{2}{*}{ Not Sig } \\
\hline & Female & 3.7 & .82 & .017 & & \\
\hline \multirow{2}{*}{ Assurance } & Male & 4.1 & .66 & 1.259 & \multirow{2}{*}{.787} & \multirow{2}{*}{ Not Sig } \\
\hline & Female & 4.0 & .69 & 1.267 & & \\
\hline \multirow{2}{*}{ Responsiveness } & Male & 3.9 & .84 & .236 & .336 & Not Sig \\
\hline & Female & 3.9 & .71 & .229 & & \\
\hline
\end{tabular}


International Journal of Heritage, Tourism and Hospitality Vol. (13), No. (2), September, 2019 By: Faculty of Tourism and Hotels, Fayoum University

\begin{tabular}{|c|c|c|c|c|c|c|}
\hline \multicolumn{2}{|l|}{ Factors } & $\mathrm{M}$ & SD & T-Value & Sig & Sig \\
\hline \multirow{2}{*}{ Reliability } & Male & 3.9 & .66 & 1.388 & \multirow{2}{*}{.658} & \multirow{2}{*}{ Not Sig } \\
\hline & Female & 3.7 & .63 & 1.379 & & \\
\hline \multirow{2}{*}{ Tangibility } & Male & 3.7 & .61 & -.643 & \multirow{2}{*}{.305} & \multirow{2}{*}{ Not Sig } \\
\hline & Female & 3.7 & .53 & -.628 & & \\
\hline \multirow{2}{*}{$\begin{array}{l}\text { Eco- activities and } \\
\text { Sustainable Practices }\end{array}$} & Male & 3.3 & .82 & .428 & \multirow{2}{*}{.232} & \multirow{2}{*}{ Not Sig } \\
\hline & Female & 3.3 & .72 & .418 & & \\
\hline
\end{tabular}

Statistically, paired sample T-test show that all service quality dimensions t-sig are more than 0.05 ( $\mathrm{P}>0.05$ ), (Finn et al., 2000), which mean that the previous service quality dimensions' differences are not significance and there is a not differences between male and female in what they actually perceived from Eco-lodge service quality. Also, all coefficient alphas are greater than 0.7 and therefore acceptable (Nunnally, 1978).

Table 13: Age Differences in ECO-SERQUAL Model

\begin{tabular}{|c|c|c|c|}
\hline Factors & F-value & Sig & Attitude \\
\hline \multicolumn{4}{|l|}{ Empathy } \\
\hline Less than 25 & \multirow[t]{4}{*}{.866} & \multirow[t]{4}{*}{.460} & \multirow[t]{4}{*}{ Not Sig } \\
\hline 25 to less than 40 & & & \\
\hline 40 to less than 60 & & & \\
\hline 60 and above & & & \\
\hline \multicolumn{4}{|l|}{ Assurance } \\
\hline Less than 25 & \multirow[t]{4}{*}{3.005} & \multirow[t]{4}{*}{.032} & \multirow[t]{4}{*}{ Sig } \\
\hline 25 to less than 40 & & & \\
\hline 40 to less than 60 & & & \\
\hline 60 and above & & & \\
\hline \multicolumn{4}{|l|}{ Responsiveness } \\
\hline Less than 25 & \multirow[t]{4}{*}{1.574} & \multirow[t]{4}{*}{.197} & \multirow[t]{4}{*}{ Not Sig } \\
\hline 25 to less than 40 & & & \\
\hline 40 to less than 60 & & & \\
\hline 60 and above & & & \\
\hline \multicolumn{4}{|l|}{ Reliability } \\
\hline Less than 25 & \multirow[t]{4}{*}{3.898} & \multirow[t]{4}{*}{.010} & \multirow[t]{4}{*}{ Sig } \\
\hline 25 to less than 40 & & & \\
\hline 40 to less than 60 & & & \\
\hline 60 and above & & & \\
\hline \multicolumn{4}{|l|}{ Tangibility } \\
\hline Less than 25 & \multirow[t]{4}{*}{.531} & \multirow[t]{4}{*}{.662} & \multirow[t]{4}{*}{ Not Sig } \\
\hline 25 to less than 40 & & & \\
\hline 40 to less than 60 & & & \\
\hline 60 and above & & & \\
\hline \multicolumn{4}{|c|}{ Eco- activities and Sustainable Practices } \\
\hline Less than 25 & \multirow[t]{4}{*}{1.088} & \multirow[t]{4}{*}{.356} & \multirow[t]{4}{*}{ Not Sig } \\
\hline 25 to less than 40 & & & \\
\hline 40 to less than 60 & & & \\
\hline 60 and above & & & \\
\hline
\end{tabular}


ANOVA analysis highlights that empathy $(\mathrm{F}=.460)$, responsiveness $(\mathrm{F}=.197)$, tangibility $(\mathrm{F}=.662)$, Eco- activities and sustainable practices $(\mathrm{F}=.356)$ and $\mathrm{P}>0.05$ which mean a not significant variance between which mean that the previous service quality dimensions' differences are not significance and there is a not differences between age group in what they actually perceived from Eco-lodge service quality. Also, all coefficient alphas are greater than 0.7 and therefore acceptable (Nunnally, 1978).

Additionally, ANOVA analysis highlights that assurance $(\mathrm{F}=.032)$, reliability $(\mathrm{F}=.010)$ and $\mathrm{P}<$ 0.05 which mean a significant variance between which mean that the previous service quality dimensions' differences are significance and there is a differences between age group in what they actually perceived from Eco-lodge service quality. Also, all coefficient alphas are greater than 0.7 and therefore acceptable (Nunnally, 1978).

Table 14: Martial Statue Differences in ECO-SERQUAL Model

\begin{tabular}{|c|c|c|c|}
\hline Factors & F- value & Sig & Attitude \\
\hline \multicolumn{4}{|c|}{ Empathy } \\
\hline Single & \multirow[t]{4}{*}{1.770} & \multirow[t]{4}{*}{.154} & \multirow[t]{4}{*}{ Not Sig } \\
\hline Married & & & \\
\hline Widowed & & & \\
\hline Divorced & & & \\
\hline \multicolumn{4}{|c|}{ Assurance } \\
\hline Single & \multirow[t]{4}{*}{.945} & \multirow[t]{4}{*}{.420} & \multirow[t]{4}{*}{ Not Sig } \\
\hline Married & & & \\
\hline Widowed & & & \\
\hline Divorced & & & \\
\hline \multicolumn{4}{|c|}{ Responsiveness } \\
\hline Single & \multirow[t]{4}{*}{2.192} & \multirow[t]{4}{*}{.090} & \multirow[t]{4}{*}{ Not Sig } \\
\hline Married & & & \\
\hline Widowed & & & \\
\hline Divorced & & & \\
\hline \multicolumn{4}{|c|}{ Reliability } \\
\hline Single & \multirow[t]{4}{*}{1.416} & \multirow[t]{4}{*}{.239} & \multirow[t]{4}{*}{ Not Sig } \\
\hline Married & & & \\
\hline Widowed & & & \\
\hline Divorced & & & \\
\hline \multicolumn{4}{|c|}{ Tangibility } \\
\hline Single & \multirow[t]{4}{*}{1.213} & \multirow[t]{4}{*}{.306} & \multirow[t]{4}{*}{ Not Sig } \\
\hline Married & & & \\
\hline Widowed & & & \\
\hline Divorced & & & \\
\hline \multicolumn{4}{|c|}{ Eco- activities and Sustainable Practices } \\
\hline Single & \multirow[t]{4}{*}{.881} & \multirow[t]{4}{*}{.452} & \multirow[t]{4}{*}{ Not Sig } \\
\hline Married & & & \\
\hline Widowed & & & \\
\hline Divorced & & & \\
\hline
\end{tabular}

ANOVA analysis highlights that empathy $(\mathrm{F}=. .154)$, assurance $(\mathrm{F}=.420)$, responsiveness $(\mathrm{F}=.090)$, reliability $(\mathrm{F}=.239)$ tangibility $(\mathrm{F}=.306)$, Eco- activities and sustainable practices 
$(\mathrm{F}=.452)$ and $\mathrm{P}>0.05$ which mean a not significant variance between which mean that the previous service quality dimensions' differences are not significance and there is a not differences between martial statue of guests in what they actually perceived from Eco-lodge service quality. Also, all coefficient alphas are greater than 0.7 and therefore acceptable (Nunnally, 1978).

Table 15: Education level Differences in ECO-SERQUAL Model

\begin{tabular}{|c|c|c|c|}
\hline Factors & F- value & Sig & Attitude \\
\hline \multicolumn{4}{|c|}{ Empathy } \\
\hline High school education & \multirow[t]{4}{*}{.364} & \multirow[t]{4}{*}{.779} & \multirow[t]{4}{*}{ Not Sig } \\
\hline Bachelor degree & & & \\
\hline Master degree & & & \\
\hline Ph.D. degree & & & \\
\hline \multicolumn{4}{|c|}{ Assurance } \\
\hline High school education & \multirow[t]{4}{*}{2.270} & \multirow[t]{4}{*}{.082} & \multirow[t]{4}{*}{ Not Sig } \\
\hline Bachelor degree & & & \\
\hline Master degree & & & \\
\hline Ph.D. degree & & & \\
\hline \multicolumn{4}{|c|}{ Responsiveness } \\
\hline High school education & \multirow[t]{4}{*}{3.805} & \multirow[t]{4}{*}{.011} & \multirow[t]{4}{*}{ Sig } \\
\hline Bachelor degree & & & \\
\hline Master degree & & & \\
\hline Ph.D. degree & & & \\
\hline \multicolumn{4}{|c|}{ Reliability } \\
\hline High school education & \multirow[t]{4}{*}{2.899} & \multirow[t]{4}{*}{.036} & \multirow[t]{4}{*}{ Sig } \\
\hline Bachelor degree & & & \\
\hline Master degree & & & \\
\hline Ph.D. degree & & & \\
\hline \multicolumn{4}{|c|}{ Tangibility } \\
\hline High school education & \multirow[t]{4}{*}{.744} & \multirow[t]{4}{*}{.527} & \multirow[t]{4}{*}{ Sig } \\
\hline Bachelor degree & & & \\
\hline Master degree & & & \\
\hline Ph.D. degree & & & \\
\hline \multicolumn{4}{|c|}{ Eco- activities and Sustainable Practices } \\
\hline High school education & \multirow[t]{4}{*}{1.845} & \multirow[t]{4}{*}{.140} & \multirow[t]{4}{*}{ Not Sig } \\
\hline Bachelor degree & & & \\
\hline Master degree & & & \\
\hline Ph.D. degree & & & \\
\hline
\end{tabular}

ANOVA analysis highlights that empathy $(\mathrm{F}=.779)$, assurance $(\mathrm{F}=.082)$, tangibility $(\mathrm{F}=.527)$, Eco- activities and sustainable practices $(\mathrm{F}=.140)$ and $\mathrm{P}>0.05$ which mean a not significant variance between which mean that the previous service quality dimensions' differences are not significance and there is a not differences between educational level of Eco guests in what they actually perceived from Eco-lodge service quality. Also, all coefficient alphas are greater than 0.7 and therefore acceptable (Nunnally, 1978). 
Additionally, ANOVA analysis highlights that responsiveness $(\mathrm{F}=.011)$, reliability $(\mathrm{F}=.036)$ and $\mathrm{P}<0.05$ which mean a significant variance between which mean that the previous service quality dimensions' differences are t significance and there is a differences between educational level of Eco guests in what they actually perceived from Eco-lodge service quality. Also, all coefficient alphas are greater than 0.7 and therefore acceptable (Nunnally, 1978).

\section{Results discussion}

This study showed that (69.8\%) of Eco-lodge who responded to the survey were from Egypt, $(21 \%)$ from other countries such as Canada, Italia, USA, and UK...etc. The majority of the guests were between the ages of 25 less than 40, highly educated (61.4\%) had at least a Bachelor's degree), worked full-time (51.5\%), and almost the Eco-guest had an annual income over $12000 \$(29.7 \%)$. In terms of accommodation characteristics, the average length of stay at the Eco-lodge was three nights $(85.6 \%)$. Most of the guests visiting Eco-lodge with their friends (56.4\%). The internet, travel guidebooks and recommendations from friends and relatives were the three most important sources of information that influence on guests' decision making the process to choose the Eco-lodge. This indicates that there has been a change in marketing approaches with the rapid advancement of internet technology in the past decade (see in Table 16).

Table 16: Profiling Eco-lodge Guest in Egypt

\begin{tabular}{|c|c|c|c|c|}
\hline \multirow[b]{2}{*}{$\begin{array}{l}\text { Demographic \& } \\
\text { characteristics }\end{array}$} & \multirow[b]{2}{*}{ Current study } & \multicolumn{2}{|c|}{ Findings } & \multirow[b]{2}{*}{ Literature Review } \\
\hline & & Frequency & $\%$ & \\
\hline Gender & Female & 114 & 56.4 & \\
\hline Age Group & $26-40$ & 118 & 58.4 & Perera, 2015 \& Ban and Ramsaran, 2016 \\
\hline Martial statue & Single & 108 & 53.5 & Adalilar, et al., 2015 \\
\hline Education & Bachelor degree & 124 & 61.4 & $\begin{array}{l}\text { Ramcharjee, 2012, Adalilar, et al., } 2015 \\
\text { Kwan et al., } 2010\end{array}$ \\
\hline Nationality & $\begin{array}{l}\text { Domestic Guest } \\
\text { (Egyptian) }\end{array}$ & 141 & 69.8 & $\begin{array}{l}\text { Wight (1996a) } \\
\text { Higham et al., (2001) }\end{array}$ \\
\hline $\begin{array}{l}\text { Employment } \\
\text { status }\end{array}$ & $\begin{array}{l}\text { Employed full } \\
\text { time }\end{array}$ & 104 & 51.5 & $\begin{array}{l}\text { Ramcharjee, } 2012 \\
\text { Kwan et al., } 2010 \\
\text { Ban and Ramsaran, } 2016\end{array}$ \\
\hline $\begin{array}{l}\text { Party } \\
\text { composition }\end{array}$ & $\begin{array}{l}\text { Friends and } \\
\text { Family }\end{array}$ & 114 & 56.4 & $\begin{array}{l}\text { perera, } 2015 \\
\text { Kwan et al., } 2010 \\
\text { Ban and Ramsaran, } 2016 \\
\text { Wight (1996a) }\end{array}$ \\
\hline $\begin{array}{l}\text { Average stay in } \\
\text { Eco-lodge }\end{array}$ & 1-3 days & 173 & 85.6 & $\begin{array}{l}\text { Ramcharjee, } 2012 \\
\text { Kwan et al., } 2010 \text { perera, } 2015 \\
\text { Ban and Ramsaran, } 2016\end{array}$ \\
\hline $\begin{array}{l}\text { Annual income } \\
\text { (USA) }\end{array}$ & $\begin{array}{ll}\text { More } & \text { than } \\
12000 \$ & \end{array}$ & 60 & 29.7 & $\begin{array}{l}\text { Adalilar, et al., } 2015 \\
\text { Kwan et al., } 2010 \\
\text { perera, } 2015\end{array}$ \\
\hline $\begin{array}{l}\text { Sources of } \\
\text { Information } \\
\text { about Eco- } \\
\text { lodge }\end{array}$ & $\begin{array}{l}\text { Friends/relatives } \\
\text { Internet }\end{array}$ & 95 & 47.0 & $\begin{array}{l}\text { Perera, } 2015 \\
\text { Ramcharjee, 2012, } \\
\text { Kwan et al., } 2010\end{array}$ \\
\hline
\end{tabular}




\section{Conclusion and Recommendations}

To explore a profile of eco-guests' demographics (e.g. age, education, family status, income, etc.) and eco-guest characteristics, including party composition, length of stay and sources of information an empirical investigation of Egyptian Eco-lodge guests was conducted. This study was carried out using the survey questionnaire, which was distributed to 250 Eco-guests. From the original sample, 202 questionnaires were used, representing a $70.1 \%$ response rate. The purpose of this research determines the demographic and characteristics of Eco-lodge guests. Also, this study compared the perceived Eco-lodge service quality differs according to some of the guests' characteristics. The Egyptian Eco-lodge owner and manager need focus more on single guest, age group between 25 to 40, domestic Eco-tourist and international Eco-tourists and highly educate guest for marketing purpose. Furthermore, the manger take in consideration the difference between eco-lodge guest in perceived service quality according to the guests' education level and age group for marketing and services purpose. The future direction for the research in this area how segmentation eco-lodge guests in Egypt context and what is the marketing tools matching with this segmentation.

\section{References}

Adalilar, S. N., Alkibay, S., \& Eser, Z. (2015). Ecovillages as a Destination and a Study of Consumer Approaches to Ecovillages. Procedia economics and finance, 23, 539-546.

Akbaba, A. (2006). Measuring service quality in the hotel industry: A study in a business hotel in Turkey. International journal of hospitality management, 25(2), 170-192.

Ban, J., \& Ramsaran, R. R. (2016). An exploratory examination of service quality attributes in the ecotourism industry. Journal of Travel \& Tourism Marketing, 34(1), 132-148.

Barany, M.E., Hammett, A.L., Shillington, L.J. and Murphy, B.R. (2001) The role of private wildlife reserves in Nicaragua's emerging ecotourism industry. Journal of Sustainable Tourism, (2), 95-110

Bastic, M., \& Gojcic, S. (2012). Measurement scale for eco-component of hotel service quality. International Journal of Hospitality Management, 31(3), 1012-1020.

Black, R., \& Crabtree, A. (Eds.). (2007). Quality assurance and certification in ecotourism_(Vol. 5). CABI.

Carmody, J. (2008). Profiling specialist accommodation operators in the nature-based tourism sector of North Queensland. CAUTHE 2008: Tourism and Hospitality Research, Training and Practice; 847.

Chan, J. K. L. (2010). Assessing key satisfiers and sustainable ecolodge experience management through profile accumulation techniques. World Applied Sciences Journal, 10 (Special issue of Tourism \& Hospitality), 78-90.

Getty, J. M., \& Getty, R. L. (2003). Lodging quality index (LQI): assessing customers' perceptions of quality delivery. International Journal of Contemporary Hospitality Management, 15(2), 94-104.

Hawkins, D. (1994). The ecolodge sourcebook for planners \& developers. International Ecotourism Society.

Jackson, L. A. (2010). Toward a framework for the components of green lodging. Journal of Retail \& Leisure Property, 9(3), 211-230.

Karunaratne, W., \& Jayawardena, L., (2010). Assessment of customer satisfaction in a five star hotel-A case study. Tropical Agricultural Research, 21(3): 258 - 265 
Khan, M. (2003). ECOSERV: Ecotourists' quality expectations. Annals of tourism research, 30(1), 109-124.

Knutson, B., Stevens, P., Wullaert, C., Patton, M., \& Yokoyama, F. (1990). LODGSERV: A service quality index for the lodging industry. Hospitality Research Journal, 14(2), 277-284.

Lai, P.H. and Shafer, S. (2005) Marketing ecotourism through the Internet: An evaluation of selected ecolodges in Latin America and the Caribbean. Journal of Ecotourism 4 (3), 143160.

Mackoy, R.D. and Osland, G.E. (2004) Lodge selection and satisfaction: Attributes valued by ecotourists. Journal of Tourism Studies 15(2), 13-25.

Mehta, H. (2000). Best Practices in Ecolodge Planning, Design and Guidelines. In Ecolodge Forum-Red Sea Sustainable Tourism Initiative. Cairo.

Mehta, H. (2005). Planning, Design and Construction Guidelines for Desert Ecolodges. Kingdom of Saudi Arabia.

Parasuraman, A., Berry, L. L., \& Zeithaml, V. A. (1991). Refinement and reassessment of the SERVQUAL scale. Journal of retailing, 67, 420-450

Parasuraman, A., Zeithaml, V. A., \& Berry, L. L. (1985). A conceptual model of service quality and its implications for future research. Journal of marketing, 49(4), 41-50.

Parasuraman, A., Zeithaml, V. A., \& Berry, L. L. (1988). Servqual: A multiple-item scale for measuring consumer perc. Journal of retailing, 64(1), 12-40.

Parasuraman, A., Zeithaml, V. A., \& Berry, L. L. (1994). Reassessment of expectations as a comparison standard in measuring service quality: implications for further research. Journal of marketing, 58(1), 111-124.

Perera, P. K. P., Sumanapala, H. D. P., Kotagama, S. W., \& Silva, D. A. C. S. (2015). Eco-Lodge Patrons' Characteristics; The Sri Lankan Perspective. International Research Journal of social science, 5(2), 509-525.

Raspor, S. (2010). Measuring Perceived Service Quality Using SERVQUAL: A Case Study of the Croatian Hotel Industry. Management (18544223), 5(3).

Reichheld, F. F., \& Sasser, W. E. (1990). Zero defeofions: Quality comes to services. Harvard business review, 68(5), 105-111.

Saez, C. A., Fuentes-Fuentes, M. M., \& Lloréns-Montes, F. J. (2007). Service quality measurement in rural accommodation. Annals of Tourism Research, 34(1), 45-65.

Sanders, E.G. and Halpenny, E. (2001) The Business of Ecolodges: A Survey of Ecolodge Economics and Finance. Burlington, VT: The International Ecotourism Society

Tefera, O., \& Govender, K. (2014). From SERVQUAL to HOTSPERF: Towards the Development and Validation of an alternate Hotel Service Quality Measurement Instrument. African Journal of Hospitality, Tourism and Leisure, 5(4).

Tourism development Authority, (2008) Ecolodge Planning, Design and operation Manual Handbook.Cairo, Egypt.

Wight, P.A. (1997) Ecotourism accommodation spectrum: Does supply match the demand? Tourism Management 18 (4), 209-220

Wong Ooi Mei, A., Dean, A. M., \& White, C. J. (1999). Analysing service quality in the hospitality industry. Managing Service Quality: An International Journal, 9(2), 136-143. 
Yilmaz, I. (2009). Measurement of service quality in the hotel industry. Anatolia, 20(2), 375386.9(3), 520-529.

Yusof, N.'A., Rahman, F. A., Jamil, M. F. C., \& Iranmanesh, M. (2014). Measuring thequality of ecotourism services: Case study-based model validation.SAGE Open, 4(2).

lee, H., Lee, Y. and Yoo, D. (2000), "The determinants of perceived service quality and its relationship with satisfaction", Journal of Service Marketing, Vol. 14 No. 3, pp. 217-23.

Lai, P. H., \& Shafer, S. (2005). Marketing ecotourism through the Internet: An evaluation of selected ecolodges in Latin America and the Caribbean. Journal of Ecotourism, 4(3), 143160 .

Lu, W., \& Stepchenkova, S. (2012). Ecotourism experiences reported online: Classification of satisfaction attributes. Tourism management, 33(3), 702-712. 